\title{
IMPLEMENTASI METODE COLLABORATIVE FILTERING UNTUK REKOMENDASI CO-WORKING SPACE
}

\author{
${ }^{1)}$ Ayudina Nur Afifah, ${ }^{2)}$ Fitri Dwi Pussandha, ${ }^{3)}$ Herlisa Dewi \\ Sistem Informasi, Fakultas Ilmu Komputer, Universitas Mercu Buana \\ Jl Meruya Selatan No.1 RT 04 RW 01 Meruya Selatan, Kembangan Jakarta Barat 11650 \\ E-Mail: \\ 41815110031@student.mercubuana.ac.id,41815110032@student.mercubuana.ac.id,'41815110013@student.me \\ rcubuana.ac.id
}

\begin{abstract}
ABSTRAK
Ekonomi kreatif di Indonesia terus menunjukan peningkatan, salah satunya adalah bisnis startup yang terbukti dari banyaknya startup yang mencapai 992 startup, jumlah tersebut didominasi oleh kawasan Jabodetabek yang berjumlah 522 startup, Sumatera sebanyak 115, Jawa Timur sebanyak 113, Yogyakarta sebanyak 54 dan diikuti oleh kota-kota lainnya. Para startup atau freelancer mengalami kesulitan dalam mencari dan menentukan coworking space yang sesuai dengan keinginan dikarenakan website co-working space yang ada saat ini hanya diperuntukkan untuk co-working space itu sendiri sehingga apabila pengguna ingin membandingkan harga atau fasilitas dengan co-working space yang lain maka pengguna perlu membuka semua website dari co-working space yang lain. Penelitian ini bertujuan untuk membantu startup atau freelancer dalam mencari dan menentukan coworking space yang sesuai dengan kriteria menggunakan metode collaborative filtering. Collaborative Filtering merupakan metode untuk memberikan rekomendasi berdasarkan hasil rating dari pengguna yang lain yang memiliki tingkah laku yang sama. Metode collaborative filtering yang digunakan adalah item-based collaborative filtering. Penelitian ini dimulai dari proses pengumpulan data dengan cara membagikan kuisioner kepada responden, analisa kebutuhan, tahap pengembangan sistem, laporan hasil penelitian, dan pembuatan jurnal. Hasil dari penelitian ini yaitu sebuah website yang terdiri dari kumpulan co-working space yang ada di kawasan Jabodetabek sehingga dapat memudahkan pengguna dalam mencari dan menentukan co-working space dalam satu website.
\end{abstract}

Kata Kunci: co-working space, collaborative filtering, item-based, rating.

\begin{abstract}
The creative economy in Indonesia continue to indicate the increase, one of which is a startup business as evidenced by startup to reach 992 startup, these are dominated by the area of Jabodetabek totalling as many as 522 startup, Sumatra 115, East Java as much as 113, Yogyakarta as many as 54 and was followed by other cities. The startup or freelancers have difficulty in finding and determine the co-working space that suits your wishes because the website co-working space are reserved only for co-working space itself so that when the user wants to compare prices or facility with co-working space that other users need to open all websites of the working space of the other. This research aims to help startup or freelancers in the search for and determine the co-working space that fits the criteria using the method of collaborative filtering. Collaborative Filtering is a method to provide recommendations based on the results of the rating of the other users who have the same behavior. Collaborative filtering method used is the item-based collaborative filtering. This research starts from the data collection process by means of a detailed questionnaire distributed to respondents, needs analysis, system development phase, reports the results of research, and the creation of the journal. The results of this research, namely a website that consists of a collection of co-working space that is in Jabodetabek area so it can make it easier for users to find and determine the co-working space in one website.
\end{abstract}

Keywords: co-working space, collaborative filtering, item-based, rating.

\section{PENDAHULUAN}

Ekonomi kreatif di Indonesia terus menunjukan peningkatan yang signifikan, salah satunya adalah pada bisnis startup. Meningkatnya jumlah startup membuat beberapa kota di Indonesia ikut menyediakan tempat atau sarana bagi mereka untuk mengembangkan kreativitas sekaligus berkolaborasi dengan startup lainnya, khususnya di kawasan Jabodetabek, karena kawasan tersebut merupakan kawasan dengan jumlah startup terbanyak di Indonesia. Salah 
satu tempat atau sarana yang dapat digunakan untuk kegiatan tersebut adalah co-working space. Co-working space merupakan area kerja yang didalamnya terdapat lingkungan serta jaringan yang terhubung dengan pengguna lainnya dan membentuk komunitas, sehingga dapat mengubah cara seseorang dalam bekerja [1]. Suatu co-working space pada umumnya memiliki website tersendiri yang digunakan pengelola untuk berinteraksi dengan penggunanya. Dengan sistem yang ada saat ini itu artinya pengguna diharuskan membuka setiap website co-working space yang ada untuk mendapatkan informasi tersebut, belum lagi pengguna juga diharuskan mengetahui alamat website coworking space. Selain itu dari sisi pengelola co-working space, sulitnya melakukan promosi dan menambah jumlah pemesanan masih menjadi kendala yang ada saat ini, akan lebih baik apabila pengelola dapat memasarkan tempatnya secara luas dan tidak hanya mengandalkan website milik sendiri sehingga co-working space dapat lebih dikenal lagi oleh pengguna. Berdasarkan penelitian yang dilakukan oleh leny indah sari, ofita purwani, dan leny pramesti dengan judul Co-Working Space As A Creative Collaborative Space Of Community Centre In Purwokerto. Fenomena munculnya bisnis startup membuat kota-kota besar di Indonesia khususnya Purwokerto menciptakan sarana untuk digunakan oleh masyarakatnya dalam mengembangkan kreatifitas dan inovasi. Salah satunya yaitu dengan menghadirkan suatu co-working space [1]. Penelitian ini melakukan implementasi metode collaborative filtering untuk merekomendasikan co-working space yang sesuai dengan kriteria pengguna. Metode collaborative filtering yang dipilih yaitu itembased collaborative filtering. Item-based collaborative filtering merupakan rekomendasi yang didasari atas adanya kesamaan pemberian rating terharap suatu item dengan item yang dicari [2]. Penelitian ini dimulai dari proses pengumpulan data dengan cara membagikan kuisioner kepada responden, melakukan analisa kebutuhan seperti: pembuatan rancangan layar aplikasi, rancangan basis data, use case, activity diagram dan sequence diagram. Selanjutnya melakukan pengembangan sistem dengan menggunakan bahasa pemrograman PHP dengan framework CodeIgniter dan database yang digunakan adalah MySQL. Setelah itu menyusun laporan hasil penelitian, dan yang terakhir pembuatan jurnal. Penelitian ini menghasilkan sebuah website yang berisi kumpulan beberapa co-working space pada kawasan Jabodetabek. Dengan adanya website tersebut diharapkan dapat membantu pengguna dalam mencari dan menentukan coworking space sesuai dengan kriteria tanpa harus membuka banyak website co-working space.

\section{Collaborative Filtering}

Collaborative filtering (CF) merupakan suatu konsep yang digunakan untuk memberikan rekomendasi berdasarkan pendapat dari pengguna lain yang memiliki tingkah laku yang sama. Tujuan dari collaborative filtering adalah untuk memberikan saran kepada seseorang mengenai item baru berdasarkan pendapat dan minat dari pengguna sebelumnya. [3]. Salah satu jenis collaborative filtering yang digunakan untuk penelitian ini adalah Item Based Collaborative Filtering. Item based collaborative filtering adalah suatu metode yang digunakan untuk memberikan rekomendasi berdasarkan kesamaan antara item yang dihitung menggunakan penilaian orang atas item tersebut [3]. 


\section{Co-working Space}

Co-working space atau ruang kerja bersama adalah suatu tempat bagi pekerja mandiri berbagi ruang untuk bekerja. Tujuannya bukan sekedar menyewakan ruang kerja saja, melainkan sebagai tempat untuk memperluas jaringan sehingga dapat menghasilkan ide-ide baru [1].

\section{METODE}

Metode Penelitian yang dilakukan ditujukan pada gambar 1 .

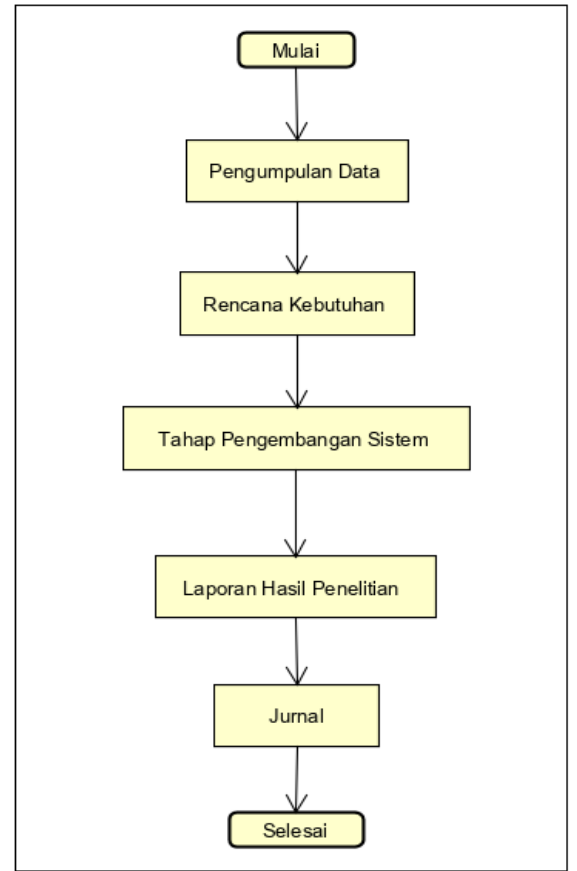

Gambar 1. Diagram Alir Penelitian

Penjelasan diagram alir penelitian sebagai berikut:

\section{Pengumpulan Data}

Pengumpulan data dilakukan dengan cara membagikan kuisioner kepada responden dan melakukan studi pustaka melalui beberapa jurnal dan buku.

\section{Rencana Kebutuhan}

Perencanaan kebutuhan dengan melakukan analisa data, membuat rancangan layar, use case diagram, activity diagram, sequence diagram, dan rancangan basis data.

\section{Pengembangan Sistem}

Pengembangan sistem yang terdiri dari beberapa tahap:

\section{a. Planning}

Pada tahap ini dimulai dengan mengumpulkan kebutuhan aktifitas suatu sistem yang memungkinkan pengguna memahami proses bisnis untuk sistem dan mendapatkan gambaran yang jelas mengenai fitur utama, fungsionalitas dan keluaran yang diinginkan. Dalam pembangunan aplikasi co-working space pada tahapan ini dimulai dari mengidentifikasi masalah yang timbul pada sistem yang sedang berjalan, kemudian dilakukan analisa kebutuhan pengguna terhadap sistem yang akan dibangun.

\section{b. Design}

Pada tahap ini dilakukan pembuatan pemodelan sistem berdasarkan hasil analisa kebutuhan yang didapatkan. Selain itu dibuatkan juga pemodelan basis data untuk menggambarkan hubungan antar data. Pemodelan sistem yang digunakan yaitu UML (Unified Modelling Language) yang terdiri dari Use Case Diagram, Activity Diagram, Sequence Diagram.

\section{c. Coding}

Pada tahap ini merupakan implementasi dari perancangan sistem yang telah dibuat kedalam kode program yang menghasilkan gambaran dari aplikasi. Dalam pembangunan aplikasi Co-working Space menggunakan bahasa pemrograman PHP dengan framework CodeIgniter yang dikombinasikan dengan HTML, CSS dan Javascript. Untuk implementasi basis data menggunakan database MySQL.

\section{d. Testing}


Tahap ini merupakan tahap pengujian terhadap aplikasi yang sudah dibangun, Metode pengujian yang digunakan dengan uji aplikasi menggunakan black box testing. Dimana setiap fitur akan diberikan uji skrip tentang input, proses dan bentuk output yang diharapkan [4].

\section{Laporan Hasil Penelitian}

Laporan berisi hal-hal yang dikerjakan selama penelitian, dalam penulisannya format yang digunakan adalah berdasarkan format yang sudah ditentukan oleh Universitas Mercu Buana.

\section{Jurnal}

Melakukan penyusunan jurnal sesuai dengan format jurnal yang dipilih.

\section{HASIL}

\section{Perancangan Use Case Diagram}

Pada tahap desain menggunakan pemodelan berorientasi objek yaitu UML (Unified modeling Language). Tujuan dari pemodelan sistem adalah untuk menyederhanakan masalah yang kompleks sehingga dapat dengan mudah dipahami dan dipelajari [5]. Terdapat tiga aktor yaitu:

a. Penyewa, merupakan aktor yang memiliki hak untuk melakukan registrasi, melakukan pemesanan, melihat riwayat pemesanan yang dilakukan oleh penyewa itu sendiri, menerima notifikasi saat proses pemesanan, dan memberikan rating atau review kepada co-working space ketika masa penyewaan telah selesai.

b. Pengelola, merupakan aktor yang memiliki hak untuk melakukan registrasi, melakukan pengajuan coworking space, melihat daftar coworking space, menerima notifikasi saat admin melakukan verifikasi pengajuan co-working space. c. Admin, merupakan aktor yang mempunyai hak untuk mengelola data kota, data co-working space, memeriksa pengajuan co-working space dan memeriksa pembayaran, mencetak laporan pemesanan dan laporan pengajuan, mendapat notifikasi saat pengguna melakukan pemesanan atau melakukan pengajuan co-working space, serta melihat semua riwayat pemesanan.

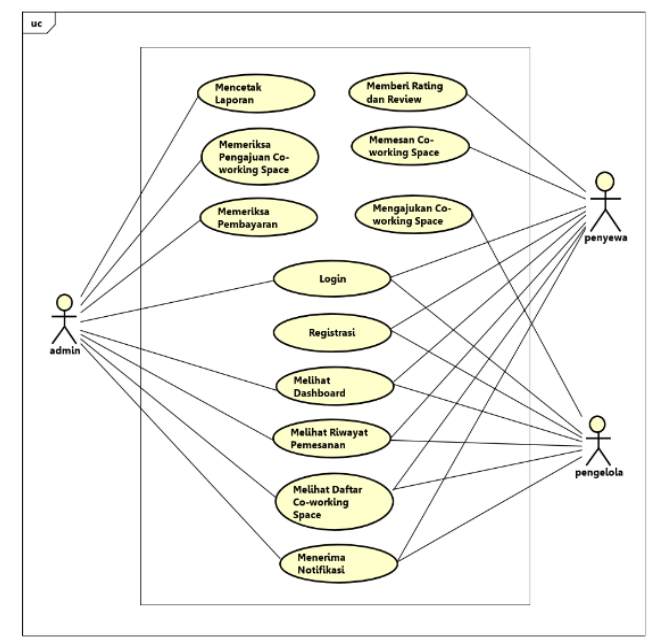

Gambar 2. Use Case Diagram

Pada sistem ini terdapat beberapa use case. Dapat dilihat pada gambar dibawah ini deskripsi dari masing-masing use case.

Table 1. Deskripsi Use Case

\begin{tabular}{lll}
\hline No & Use Case & Deskripsi \\
\hline 1 & Registrasi & Proses \\
& & mendafarkan \\
& & pengguna ke \\
& & aplikasi.
\end{tabular}

\begin{tabular}{lll}
\hline 2 & Login & $\begin{array}{l}\text { Proses input } \\
\text { username dan } \\
\text { password untuk } \\
\end{array}$ \\
& & masuk ke aplikasi. \\
\hline 3 & Memesan Co- & Proses input data \\
& working Space & untuk melakukan \\
\hline
\end{tabular}




\begin{tabular}{|c|c|c|c|c|c|}
\hline & & $\begin{array}{l}\text { pemesanan } \text { co- } \\
\text { working space. }\end{array}$ & & & $\begin{array}{l}\text { rating dan review } \\
\text { pada co-working }\end{array}$ \\
\hline \multirow[t]{2}{*}{4} & \multirow[t]{2}{*}{$\begin{array}{l}\text { Mengajukan Co- } \\
\text { working Space }\end{array}$} & $\begin{array}{l}\text { Proses input data } \\
\text { untuk mendaftarkan } \\
\text { co-working space }\end{array}$ & & & $\begin{array}{l}\text { space ketika masa } \\
\text { pemesanan telah } \\
\text { selesai. }\end{array}$ \\
\hline & & $\begin{array}{l}\text { ke aplikasi yang } \\
\text { dilakukan oleh } \\
\text { pengguna yang } \\
\text { memiliki tempat } \\
\text { kerja. }\end{array}$ & \multirow[t]{2}{*}{11} & $\begin{array}{l}\text { Mencetak } \\
\text { Laporan }\end{array}$ & $\begin{array}{l}\text { Proses } \\
\text { menampilkan data } \\
\text { laporan bulanan } \\
\text { dan tahunan pada } \\
\text { pemesanan dan }\end{array}$ \\
\hline \multirow[t]{2}{*}{5} & \multirow{2}{*}{$\begin{array}{l}\text { Memeriksa } \\
\text { Pengajuan Co- } \\
\text { working Space }\end{array}$} & $\begin{array}{l}\text { Proses melakukan } \\
\text { pengecekan detail }\end{array}$ & & & $\begin{array}{l}\text { pengajuan co- } \\
\text { working space. }\end{array}$ \\
\hline & & $\begin{array}{l}\text { data co-working } \\
\text { space yang telah } \\
\text { diajukan. }\end{array}$ & \multirow[t]{2}{*}{12} & \multirow[t]{2}{*}{ Dashboard } & $\begin{array}{l}\text { Proses } \\
\text { menampilkan data } \\
\text { pergerakan }\end{array}$ \\
\hline 6 & $\begin{array}{l}\text { Memeriksa } \\
\text { Pembayaran }\end{array}$ & $\begin{array}{l}\text { Proses melakukan } \\
\text { pengecekan bukti } \\
\text { bayar yang telah } \\
\text { melakukan }\end{array}$ & & & $\begin{array}{l}\text { pemesanan tiap } \\
\text { minggu dan jumlah } \\
\text { pengajuan co- } \\
\text { working space. }\end{array}$ \\
\hline
\end{tabular}

pemesanan $\mathrm{co}$ -

working space.

\begin{tabular}{|c|c|c|}
\hline 7 & $\begin{array}{l}\text { Melihat Riwayat } \\
\text { Pemesanan }\end{array}$ & $\begin{array}{l}\text { Proses } \\
\text { menampilkan data } \\
\text { riwayat pemesanan } \\
\text { co-working space. }\end{array}$ \\
\hline 8 & $\begin{array}{l}\text { Melihat Daftar } \\
\text { Co-working } \\
\text { Space }\end{array}$ & $\begin{array}{l}\text { Proses } \\
\text { menampilkan data } \\
\text { co-working space } \\
\text { yang sudah } \\
\text { terdaftar pada } \\
\text { aplikasi. }\end{array}$ \\
\hline 9 & $\begin{array}{l}\text { Menerima } \\
\text { Notifikasi }\end{array}$ & $\begin{array}{l}\text { Proses } \\
\text { menampilkan } \\
\text { notifikasi untuk } \\
\text { admin dan } \\
\text { pengguna dalam } \\
\text { bentuk chat bot } \\
\text { Telegram dan } \\
\text { dalam bentuk bar } \\
\text { notification pada } \\
\text { aplikasi. }\end{array}$ \\
\hline 10 & $\begin{array}{l}\text { Memberi Rating } \\
\text { dan Review }\end{array}$ & $\begin{array}{l}\text { Proses melakukan } \\
\text { penilaian berupa }\end{array}$ \\
\hline
\end{tabular}

\section{Basis Data}
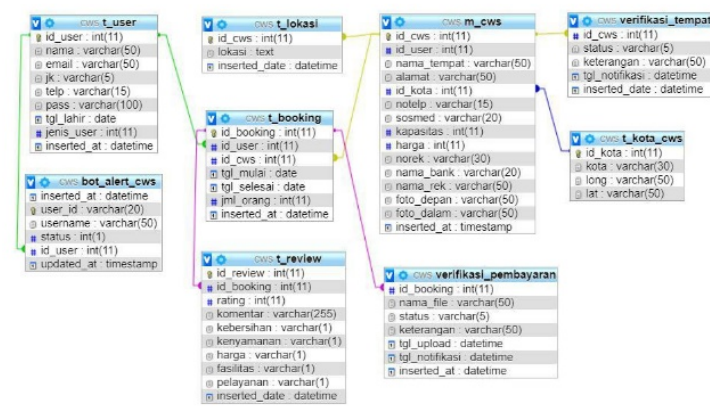

Gambar 3. Basis Data

Aplikasi co-working space memiliki 9 tabel yang terdiri dari:

- $t$ user

Tabel t_user merupakan tabel yang menyimpan data pengguna coworking space.

- m_cws

Tabel m_cws merupakan tabel yang menyimpan data dari co-working space yang diinputkan oleh pengguna 
(pengelola co-working space tersebut).

- t_booking

Tabel t_booking merupakan tabel yang menyimpan data pemesanan yang telah diinputkan oleh pengguna.

- verifikasi_pembayaran.

Tabel verifikasi pembayaran merupakan tabel yang menyimpan data bukti pembayaran yang dilakukan oleh pengguna setelah melakukan pemesanan. Data di tabel ini akan terupdate ketika admin melakukan verifikasi untuk me-reject atau approve berdasarkan kesesuaian atau tidaknya jumlah yang ditransfer oleh pengguna dan jumlah yang harus dibayarkan pengguna yang tertera pada aplikasi.

- verifikasi_tempat

Tabel verifikasi_tempat merupakan tabel yang menyimpan data daftar coworking space yang sudah diinputkan oleh pengguna. Data di tabel ini akan ter-update jika admin melakukan verifikasi terhadap co-working space yang sudah diinputkan oleh pengguna.

- t_lokasi

Tabel t_lokasi merupakan tabel yang menyimpan data embedded maps dari co-working space dimana embedded maps tersebut diinputkan oleh admin.

- t_kota_cws

Tabel t_kota_cws merupakan tabel yang menyimpan data kota yaitu Jakarta, Bogor, Depok, Tangerang, dan Bekasi yang nantinya akan digunakan untuk mengelompokkan co-working space berdasarkan kota tersebut.

- bot_alert_cws

Tabel bo_alert_cws merupakan tabel yang menyimpan data pengguna agar mendapatkan notifikasi melalui bot Telegram.

\section{Implementasi Collaborative Filtering}

Proses menentukan rekomendasi:

1. Menghitung rata-rata user terhadap keseluruhan co-working space yang telah diberi rating oleh user.

2. Menghitung rata-rata rating per masingmasing co-working space (item).

3. Menghitung nilai kemiripan (similarity) antara satu co-working space dengan coworking space lainnya yang disebut dengan nilai similarity antar objek menggunakan algoritma Adjusted Cosine.

4. Menentukan nilai minimum atau batas minimum dari hasil nilai kemiripan coworking space yang sudah dihitung pada proses ke 3, kemudian memilih coworking space yang memiliki kemiripan.

5. Menampilkan hasil kemiripan antara 2 co-working space untuk dijadikan sebagai rekomendasi kepada user. Jika user sedang membuka salah satu dari coworking space tersebut, maka co-working space yang mirip (berasal dari proses nomor 4) akan muncul sebagai rekomendasi kepada $u s e r$.

Persamaan Adjusted Cosine:

$$
=\frac{S(i, j)}{\sqrt{\sum_{u \in U}\left(R_{u, i}-\bar{R}_{u}\right)^{2}} \sqrt{\sum_{u \in U}\left(R_{u, j}-\bar{R}_{u}\right)^{2}}}
$$

Keterangan:

$S(i, j)=$ Nilai kemiripan(similarity) antara item $\mathrm{i}$ dan $\mathrm{j}$

$u \in U$ = Himpunan user yang me-rating item $\mathrm{i}$ dan $\mathrm{j}$ 
$R_{u, i} \quad=$ Nilai rating user $\mathrm{u}$ pada item $\mathrm{i}$

$\bar{R}_{i} \quad=$ Nilai rata-rata rating item $\mathrm{i}$

$R_{u, j} \quad=$ Nilai rating user $\mathrm{u}$ pada item $\mathrm{j}$

$\bar{R}_{j} \quad=$ Nilai rata-rata rating item $\mathrm{j}$

$\bar{R}_{u} \quad=$ Nilai rata-rata rating user $\mathrm{u}$ [3]

Table 2. Contoh Data

\begin{tabular}{clcc}
\hline Id rating & Id cws & Id user & $\begin{array}{l}\text { Nilai } \\
\text { rating }\end{array}$ \\
\hline 1 & $\mathrm{a}$ & 1 & 4 \\
\hline 2 & $\mathrm{a}$ & 2 & 2 \\
\hline 3 & $\mathrm{a}$ & 3 & 1 \\
\hline 4 & $\mathrm{~b}$ & 4 & 5 \\
\hline 5 & $\mathrm{~b}$ & 1 & 2 \\
\hline 6 & $\mathrm{c}$ & 2 & 2 \\
\hline 7 & $\mathrm{~b}$ & 3 & 3 \\
\hline 8 & $\mathrm{c}$ & 4 & 4 \\
\hline 9 & $\mathrm{c}$ & 1 & 3 \\
\hline 10 & $\mathrm{c}$ & 3 & 5 \\
\hline 11 & $\mathrm{~d}$ & 4 & 2 \\
\hline 12 & $\mathrm{~d}$ & 3 & 4 \\
\hline
\end{tabular}

Tabel diatas menjelaskan contoh data yang digunakan untuk perhitungan metode collaborative filtering yang terdiri dari data id cws, id user, dan rating yang diberikan oleh user kepada co-working space yang pernah dipesan sebelumnya.

Berikut ini penjelasan mengenai proses perhitungan metode collaborative filtering mulai dari perhitungan rata-rata hingga menentukan rekomendasi coworking space.

Proses 1 dan 2:

Table 3. Skenario Rating Co-working

\begin{tabular}{cccccc}
\multicolumn{7}{c}{ Space } \\
\hline & $\mathrm{a}$ & $\mathrm{b}$ & $\mathrm{c}$ & $\mathrm{d}$ & $\begin{array}{c}\text { Rata- } \\
\text { rata } \\
\text { User }\end{array}$ \\
\hline 1 & 4 & 2 & 3 & - & 3.00 \\
\hline 2 & 2 & - & 2 & - & 2,00 \\
\hline 3 & 1 & 3 & 5 & 4 & 3,25 \\
\hline 4 & - & 5 & 4 & 2 & 3,67 \\
\hline
\end{tabular}

\section{Rata- $\quad 2,33 \quad 3,33 \quad 3,50 \quad 3,00$ rata \\ CWS}

Tabel diatas menjelaskan contoh data $u$ ser yang melakukan rating terhadap co-working space yang pernah dipesan sebelumnya.

Table 4. Rata-rata Rating User

\begin{tabular}{cc}
\hline Id user & $\begin{array}{c}\text { Rata-rata rating } \\
\text { user }\end{array}$ \\
\hline 1 & 3,00 \\
\hline 2 & 2,00 \\
\hline 3 & 3,25 \\
\hline 4 & 3,67 \\
\hline
\end{tabular}

Tabel diatas menjelaskan rata-rata rating dari masing-masing user.

Table 5. Rata-rata Rating Keseluruhan

\begin{tabular}{c|c}
\multicolumn{2}{|c}{ Co-working Space } \\
\hline Id cws & $\begin{array}{c}\text { Rata-rata rating co- } \\
\text { working space }\end{array}$ \\
\hline $\mathrm{a}$ & 2,33 \\
\hline $\mathrm{b}$ & 3,33 \\
\hline $\mathrm{b}$ & 3,50 \\
\hline $\mathrm{d}$ & 3,00 \\
\hline
\end{tabular}

Tabel diatas menjelaskan rata-rata rating keseluruhan co-working space.

Proses 3:

Menghitung nilai similarity antara 2 id cws dengan rumus sebagai berikut:

$$
\begin{aligned}
& S_{(i, j)} \\
& =\frac{\sum u \in \cup\left(R_{u, i}-\bar{R}_{u}\right)\left(R_{u, j}-\bar{R}_{u}\right)}{\sqrt{\sum u \in \cup\left(R_{u, i}-\bar{R}_{u}\right)^{2}} \sqrt{\sum u \in \cup\left(R_{u, j}-\bar{R}_{u}\right)^{2}}}
\end{aligned}
$$

Keterangan: 
$S(i, j)=$ Nilai kemiripan(similarity) antara item $\mathrm{i}$ dan $\mathrm{j}$

$u \in U=$ Himpunan user yang me-rating item $\mathrm{i}$ dan $\mathrm{j}$

$R_{u, i} \quad=$ Nilai rating user u pada item $\mathrm{i}$

$\bar{R}_{i} \quad=$ Nilai rata-rata rating item $\mathrm{i}$

$R_{u, j} \quad=$ Nilai rating user u pada item $\mathrm{j}$

$\bar{R}_{j} \quad=$ Nilai rata-rata rating item $\mathrm{j}$

$\bar{R}_{u} \quad=$ Nilai rata-rata rating user $\mathrm{u}$ [3]

a. Nilai similarity id cws a dan id cws b

$$
\begin{aligned}
& S_{(a, b)}=\frac{-1,5625}{\sqrt{6,0625} \sqrt{1,0625}} \\
& S_{(a, b)}=\frac{-1,5625}{\sqrt{6,4414}} \\
& S_{(a, b)}=\frac{-1,5625}{2,5379} \\
& S_{(a, b)}=-0,6156
\end{aligned}
$$

b. Nilai similarity id cws a dan id cws c

$$
\begin{aligned}
& S_{(a, c)}=\frac{-3,9375}{\sqrt{6,0625} \sqrt{3,0625}} \\
& S_{(a, c)}=\frac{-3,9375}{\sqrt{6,0625} \sqrt{3,0625}} \\
& S_{(a, c)}=\frac{-3,9375}{\sqrt{18,56640}} \\
& S_{(a, c)}=\frac{-3,9375}{4,3088} \\
& S_{(a, c)}=-0,9138
\end{aligned}
$$

c. Nilai similarity id cws a dan id cws d

$$
\begin{aligned}
& S_{(a, d)}=\frac{-1,6875}{\sqrt{5,0625} \sqrt{0,5625}} \\
& S_{(a, d)}=\frac{-1,6875}{\sqrt{2,8476}} \\
& S_{(a, d)}=\frac{-1,6875}{1,6875} \\
& S_{(a, d)}=-1
\end{aligned}
$$

d. Nilai similarity id cws b dan id cws c

$$
\begin{aligned}
S_{(b, c)} & =\frac{-0,4375}{\sqrt{2,8314} \sqrt{3,1714}} \\
S_{(b, c)} & =\frac{-0,4375}{\sqrt{8,9795}} \\
S_{(b, c)} & =\frac{-0,4375}{2,9965} \\
S_{(b, c)} & =-0,1460
\end{aligned}
$$

e. Nilai similarity id cws b dan id cws d

$$
\begin{aligned}
S_{(b, d)} & =\frac{-2,4086}{\sqrt{1,8314} \sqrt{3,3514}} \\
S_{(b, d)} & =\frac{-2,4086}{\sqrt{6,1377}} \\
S_{(b, d)} & =\frac{-2,4086}{2,4774} \\
S_{(b, d)} & =-0,9722
\end{aligned}
$$

f. Nilai similarity id cws c dan id cws d

$$
\begin{aligned}
S_{(c, d)} & =\frac{0,7614}{\sqrt{3,1739} \sqrt{3,3514}} \\
S_{(c, d)} & =\frac{0,7614}{\sqrt{10,637}} \\
S_{(c, d)} & =\frac{0,7614}{3,2614} \\
S_{(c, d)} & =0,2334
\end{aligned}
$$

Proses 4:

\begin{tabular}{ccc}
\multicolumn{3}{c}{ Table 6. Nilai Perhitungan Similarity } \\
\hline Idcws 1 & Idcws 2 & $\begin{array}{c}\text { Nilai } \\
\text { Kemiripan }\end{array}$ \\
\hline a & b & $-0,6156$ \\
\hline a & c & $-0,9138$ \\
\hline a & d & -1 \\
\hline b & c & $-0,1460$ \\
\hline b & d & $-0,9722$ \\
\hline c & d & 0,2334 \\
\hline
\end{tabular}

Tabel diatas menjelaskan nilai kemiripan antar co-working space.

Hasil nilai kemiripan $=[-1 \mathrm{~s} / \mathrm{d}+1]$ 
Suatu co-working space akan dikatakan mirip dan akan direkomendasikan kepada user pada sistem adalah yang bernilai $>=0,2$. Nilai yang lebih kecil dari 0,2 tidak akan direkomendasikan kepada user.

\section{Proses 5:}

Table 7. Nilai Rekomendasi

\begin{tabular}{lll}
\hline Idcws 1 & Idcws 2 & Nilai Kemiripan \\
\hline C & D & 0,2334
\end{tabular}

Tabel diatas menjelaskan co-working space yang memenuhi kondisi untuk direkomendasikan kepada user adalah coworking space dengan id c dan d. Artinya jika user sedang membuka detail co-working space dengan id c, maka akan muncul rekomendasi co-working space dengan id d dan sebaliknya.

\section{Implementasi Aplikasi}

1. Halaman Login

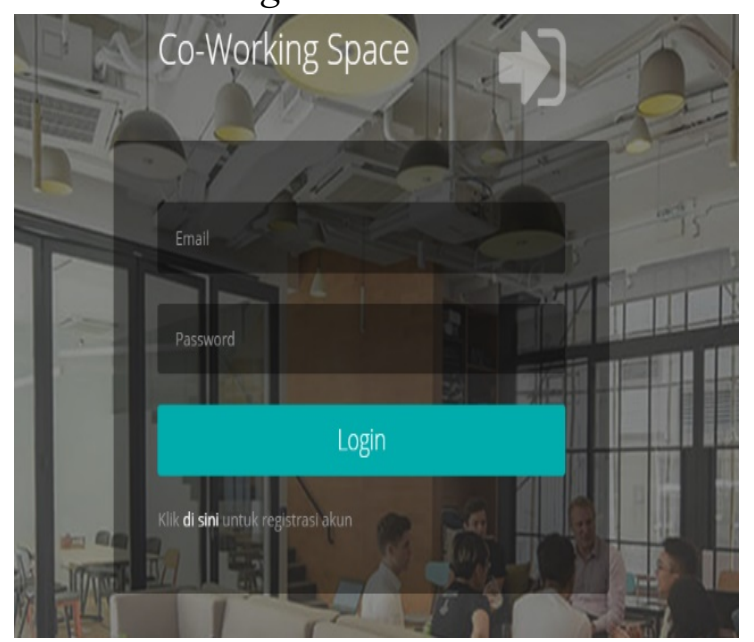

Gambar 4. Halaman Login

Menu ini digunakan oleh pengguna untuk masuk ke aplikasi dengan melakukan login. Pengguna yang dapat melakukan login merupakan pengguna yang sudah registrasi sebelumnya.

\section{Halaman Registrasi}

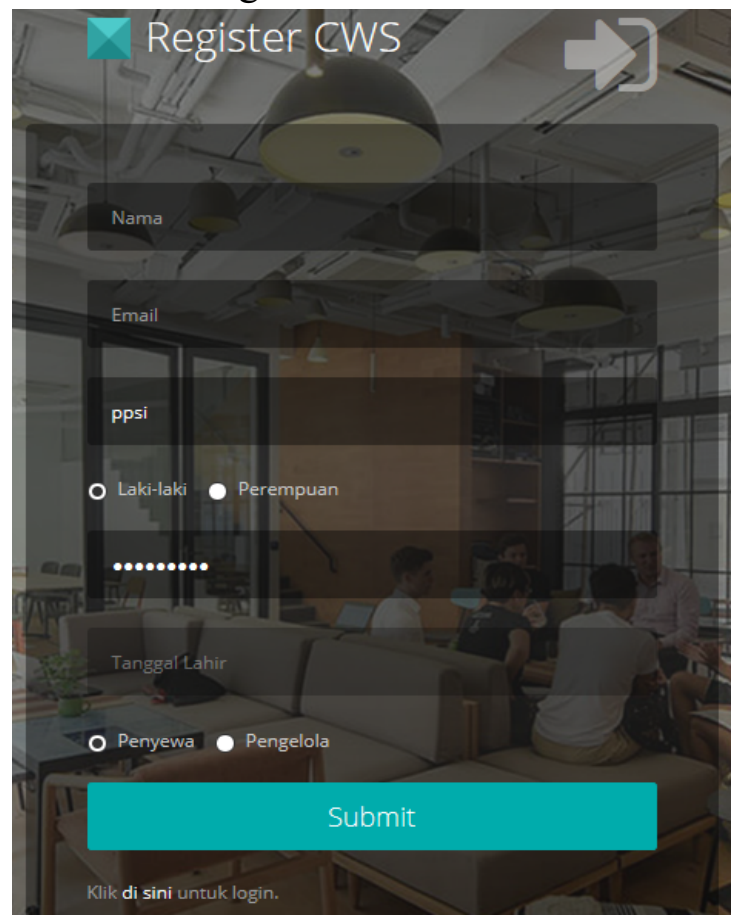

Gambar 5. Halaman Registrasi

Pada halaman ini pengguna mengisi data untuk disimpan pada sistem sebagai data pengguna co-working space. Pengguna dapat menggunakan email yang nantinya akan dijadikan sebagai username pada saat login.

\section{Tampilan Pemesanan}

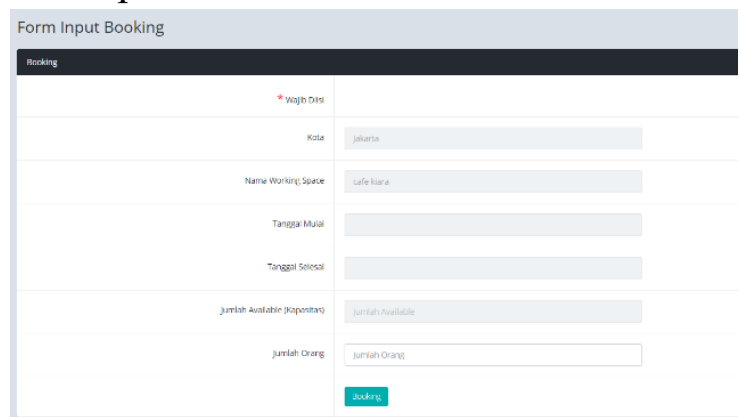

Gambar 6. Tampilan Pemesanan

Pada menu ini pengguna dapat mengisi datadata untuk melakukan pemesanan co-working space berdasarkan kota yang sudah dipilih terlebih dahulu oleh pengguna. 


\section{Tampilan Pengajuan Co-working Space}

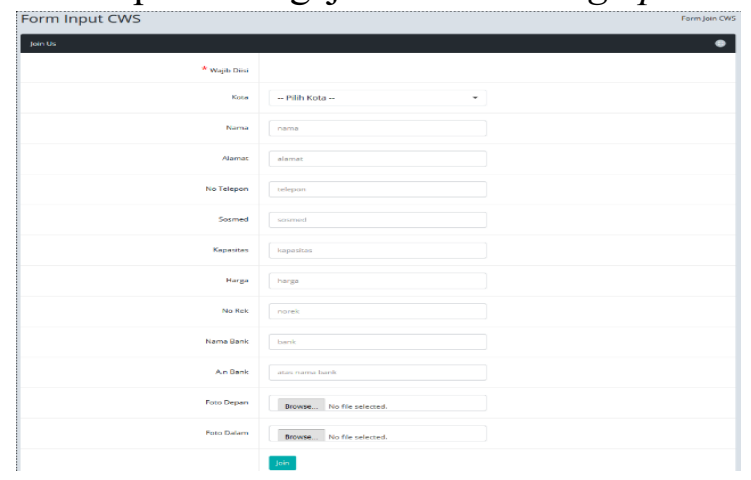

Gambar 7. Tampilan Pengajuan Coworking Space

Pada menu ini pengguna dapat melakukan pengajuan co-working space. Menu ini digunakan apabila pengguna memiliki tempat kerja yang akan diajukan ke aplikasi untuk dijadikan ruang kerja sementara.

\section{Tampilan Detail Co-working Space}

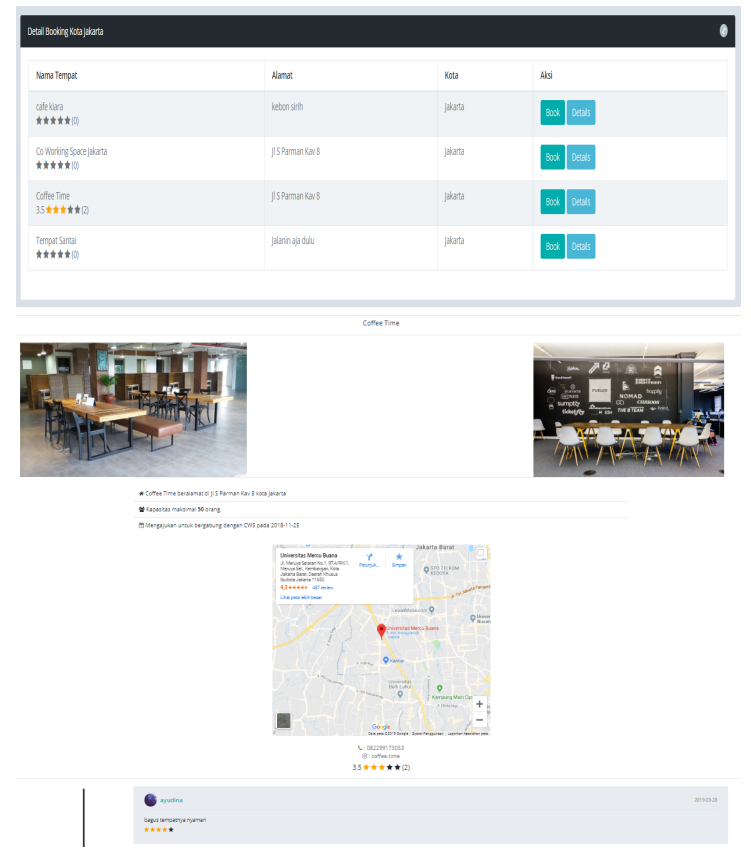

Gambar 8. Detail Co-working Space

Pada menu ini pengguna dapat melihat detail dari suatu co-working space sebelum melakukan pemesanan. Informasi seperti gambar, harga, kapasitas, lokasi serta rating DOI : https://doi.org/10.36341/rabit.v4i2.744 terhadap co-working space dapat dilihat detail pada menu ini.

\section{KESIMPULAN}

Berdasarkan penelitian dan perancangan sistem yang dilakukan maka dapat ditarik kesimpulan yaitu:

1. Aplikasi ini berfungsi untuk mempermudah penyewa dalam memesan dan menemukan co-working space yang sesuai dengan keinginan hanya dalam satu aplikasi.

2. Dengan implementasi metode item based collaborative filtering dapat membantu pengguna dalam menentukan co-working space mana yang pantas untuk dipilih berdasarkan rating dan review dari pengguna sebelumnya.

3. Berdasarkan hasil perhitungan similarity. Filter nilai similarity adalah $>=0,2$.

\section{DAFTAR PUSTAKA}

[1] Leny indah sari, Ofita purwani, dan Leny pramesti. 2018. Co-Working Space As A Creative - Collaborative Space Of Community Centre In Purwokerto. Vol 16

[2] Fathoni, Pacu Putra, Rio Abdi Sucipta. 2016. Penerapan Metode Item Based Coolaborative Filtering pada Sistem Electronic Commerce Berbasis Website. Vol 2

[3] Andreas Eko Wijaya, Deni Alfian. 2018. Sistem Rekomendasi Lapop Menggunakan Collaborative Filtering dan Content-Based Filtering. Vol 12

[4] Riad Sahara, Indra Ranggadara. 2018. Design and Implementation of Treasury Application Based on Mobile in Student Organization Mercu Buana University. Vol 7

[5] Alfianto, Yaya Sudarya Triana. 2018. Analysis and Design of Online 
RABIT : Jurnal Teknologi dan Sistem Informasi Univrab

Volume 4 No. 2 | Juli 2019 : 87-96

Ordering System of Padang Cuisine.

Vol 7 